\title{
Microstructures and deformation mechanisms of experimentally deformed gabbro
}

\author{
Yongsheng Zhou $\cdot$ Changrong He
}

Received: 20 November 2014/ Accepted: 12 February 2015/Published online: 24 March 2015

(C) The Author(s) 2015. This article is published with open access at Springerlink.com

\begin{abstract}
The natural gabbro samples were deformed at temperature ranging from 700 to $1150{ }^{\circ} \mathrm{C}$ with strain rate steps of $1 \times 10^{-4}, 2.5 \times 10^{-5}, 6.3 \times 10^{-6} \mathrm{~s}^{-1}$. The mechanical data show that sample experiences gradual transition from semi-brittle flow to plastic flow, corresponding to a systematically decreasing stress exponent $n$ with the increasing temperature ranging from 16.5 to 4.1 (He et al. Sci China (D) 46(7):730-742, 2003). We investigate microstructures and deformation mechanisms of experimentally deformed gabbro under transmission electron microscope in this study. For low temperature of $700{ }^{\circ} \mathrm{C}$ to $950{ }^{\circ} \mathrm{C}$, the deformation is mainly accommodated with dislocation glide and mechanical twinning, corresponding to stress exponent lager than 5 , which means semi-brittle deformation. Whereas with higher temperature up to 1000 ${ }^{\circ} \mathrm{C}-1150{ }^{\circ} \mathrm{C}$, the deformation is accommodated mainly with dislocation glide and climb corresponding to stress exponent of 4.1, which means plastic deformation. Evidence of dislocation climb has been found as dislocation walls in plagioclase. The observed slip system in plagioclase is (001)1/2[110] and that in clinopyroxene are (100)[001] and (010)[001]. The (010)[001] slip system in clinopyroxene is newly found in this work. Melt was found at temperature of $950{ }^{\circ} \mathrm{C}-1050{ }^{\circ} \mathrm{C}$. The melt glass distributed both in melt thin film between two grain boundaries and melt tubules of triangular along three grain boundaries at temperature of $950{ }^{\circ} \mathrm{C}-1000{ }^{\circ} \mathrm{C}$. The melt triangular interconnected to the melt film at temperature of $1050{ }^{\circ} \mathrm{C}-1150{ }^{\circ} \mathrm{C}$, where the melt chemical composition
\end{abstract}

Y. Zhou $(\bowtie) \cdot$ C. He $(\bowtie)$

State Key Laboratory of Earthquake Dynamics,

Institute of Geology, China Earthquake Administration,

Beijing 100029, China

e-mail: zhouysh@ies.ac.cn; crhe@ies.ac.cn differentiated into iron-rich dark dots and silicate-rich matrix.

Keywords Microstructure - Deformation mechanism . Transmission electron microscope (TEM) - Semi-brittle · Plastic · Gabbro

\section{Introduction}

In the lower continental crust, feldspars and pyroxenes are the most abundant minerals. In order to understand the deformation mechanisms and obtain the mechanical parameters, much attention has been paid to some multiphase and single-phase aggregates. In early researches, single crystal of clinopyroxene was investigated for relations between mechanical data and specific slip systems or mechanical twinning plane (Kollé and Blacic 1982, 1983; Kirby and Kronenberg 1984; Boland and Tullis 1986; Raterron and Jaoul 1991; Ingrin et al. 1991; Raterron et al. 1994; Jaoul and Raterron 1994). Some researchers have focused on multi-phase diabase and gabbro, which is more complicated, but believed to be similar to the composition of continental lower crust (Kronenberg and Shelton 1980; Caristan 1982; Mackwell et al. 1998; He et al. 2003). Wilks and Carter (1990) as well as Ross and Wilks $(1995,1996)$ reported flow laws for oven-dried granulite, Wang et al. (2012) examined plastic deformation on wet mafic granulite, Zhou et al. (2012a, b) studied the creep of partially molten fine-grained gabbro under dry conditions and Reaction accommodated creep of wet gabbro.

More recent experimental studies on hot-pressed mineral aggregates with known water content focussed on single- or two-phase samples of plagioclase and pyroxene. They include investigations on diffusion and dislocation 



Fig. 1 The microstructure of staring sample. a Optical micrography (Crossed polarizer); b Few dislocations in plagioclase (TEM); c Natural twins of plagioclase (TEM)

creep of synthetic anorthite aggregates (Dimanov et al. 1998, 1999, 2003; Rybacki and Dresen 2004; Rybacki and Dresen 2000; Rybacki et al. 2006, 2008, 2010), diopside (Dimanov et al. 2003, 2007), clinopyroxenite (Mauler et al. 2000; Bystricky and Mackwell 2001; Hier-Majumder et al. 2005; Chen et al. 2006), orthopyroxene (Ohuchi et al. 2011), and two-phase anorthite-diopside mixtures (Dimanov and Dresen 2005; Dimanov et al. 2007, 2011). The experiments using hot-pressed samples were mainly dedicated to better understand the mechanical constituents and flow laws of the lower crust in dependence on the thermodynamic conditions. Compared to mostly synthetic, hot-pressed single- and two-phase aggregates used in these experiments, natural rocks of the lower crust have a more complex mineralogy including different plagioclase and pyroxene compositions and various amounts of opaque minerals. Does this textural and minerals difference has significant influence on the microstructures and deformation mechanism in experimentally deformed natural samples? With the question in mind, in this study, we investigate microstructures and deformation mechanisms of experimentally deformed gabbro under transmission electron microscope (TEM) based on the mechanical data of He et al. (2003).

\section{The starting sample and experimental conditions}

The fine-grained gabbro was collected from the bottom brim of Panzhihua magnetite ore body, located in Panxi rift, Sichuan Province, China. The sample is fine-grained, with grains of different sizes, but no evident anisotropy. Major constituents are plagioclase $(50 \%)$ and clinopyroxene $(40 \%)$, with hornblende $(5 \%)$, magnetite $(4 \%)$, and chlorite $(1 \%)$. The plagioclase is rod-shaped, with an average length of $0.192 \mathrm{~mm}$, and average width of
$0.064 \mathrm{~mm}$; Clinopyroxene grain has an average length of $0.224 \mathrm{~mm}$ and average width of 0.096 . The distributions of long axis have no preferred orientation. The boundaries of minerals are distinct, and interior of minerals is clean under optical microscope (Fig. 1a). Few dislocations (Fig. 1b) but natural twins (Fig. 1c) are found in plagioclase under TEM. Samples are dried under $150{ }^{\circ} \mathrm{C}$ for $24-48 \mathrm{~h}$ before experiments. Based on Fourier-transform infrared (FTIR) measured, average water content of samples is between $0.015 \mathrm{wt} \%$ and $0.08 \mathrm{wt} \%$ with an average amount of $0.04 \mathrm{wt} \% \mathrm{H}_{2} \mathrm{O}$.

Natural gabbro samples were deformed using a triaxial testing system with a Griggs type solid medium pressure vessel (He et al. 2003). The experimental conditions are confining pressure of $450-500 \mathrm{MPa}$, and temperature of $700{ }^{\circ} \mathrm{C}-1150{ }^{\circ} \mathrm{C}$. To obtain the loading rate dependency, rate steps were applied in most runs. When the sample arrives at a macroscopically steady state corresponding to an applied loading rate, the rate is switched to a new value, getting another steady-state value of stress. Three strain rate steps are $1 \times 10^{-4}, 2.5 \times 10^{-5}$, and $6.3 \times 10^{-6} \mathrm{~s}^{-1}$. For the experimental procedure, see $\mathrm{He}$ et al. (2003).

\section{Mechanical data}

The mechanical data were reported by He et al. (2003). So, to understand the microstructures and deformation mechanism of the deformed samples, we generally introduce the data in this work.

\subsection{Stress-strain data}

In total, we deformed 7 samples at temperature of $700{ }^{\circ} \mathrm{C}-$ $1150{ }^{\circ} \mathrm{C}$ and strain rate steps are $1 \times 10^{-4}, 2.5 \times 10^{-5}$, and $6.3 \times 10^{-6} \mathrm{~s}^{-1}$ (Table 1). The strength of samples 
Table 1 Experimental conditions and mechanical data of fine-grained gabbro

\begin{tabular}{|c|c|c|c|c|c|c|c|c|c|}
\hline $\begin{array}{l}\text { Sample } \\
\text { No. }\end{array}$ & $\begin{array}{l}\text { Temperature } \\
\left({ }^{\circ} \mathrm{C}\right)\end{array}$ & $\begin{array}{l}\text { Pressure } \\
(\mathrm{MPa})\end{array}$ & $\begin{array}{l}\text { Diff. } \\
\text { stress }(\mathrm{MPa})\end{array}$ & $\begin{array}{l}\text { Strain } \\
(\%)\end{array}$ & $\begin{array}{l}\text { Strain rate } \\
\left(\mathrm{s}^{-1}\right)\end{array}$ & $n$ & $Q(\mathrm{~kJ} / \mathrm{mol})$ & $A\left(\mathrm{MPa}^{-\mathrm{n}} \mathrm{s}^{-1}\right)$ & Notes \\
\hline $20 a-31$ & 700 & 450 & $\begin{array}{l}2530.50 \\
2386.20 \\
2148.60\end{array}$ & $\begin{array}{l}15.4 \\
18.6 \\
21.3\end{array}$ & $\begin{array}{l}1.0 \times 10^{-4} \\
2.5 \times 10^{-5} \\
6.3 \times 10^{-6}\end{array}$ & $16.5 \pm 2.7$ & $612 \pm 12$ & $(8.4 \pm 7.2) \times 10^{21}$ & $\begin{array}{l}\text { With } \\
\text { microfracture }\end{array}$ \\
\hline $20 a-16$ & 800 & 450 & $\begin{array}{l}1351.64 \\
1218.83 \\
1084.49\end{array}$ & $\begin{array}{l}10.1 \\
12.8 \\
14.6\end{array}$ & $\begin{array}{l}1.0 \times 10^{-4} \\
2.5 \times 10^{-5} \\
6.3 \times 10^{-6}\end{array}$ & $12.6 \pm 0.4$ & & & no melt \\
\hline $20 a-32$ & 900 & 450 & $\begin{array}{r}1317.35 \\
1079.17 \\
921.80 \\
834.04\end{array}$ & $\begin{array}{l}14.7 \\
16.5 \\
17.7 \\
18.6\end{array}$ & $\begin{array}{l}1.0 \times 10^{-4} \\
2.5 \times 10^{-5} \\
6.3 \times 10^{-6} \\
3.1 \times 10^{-6}\end{array}$ & $7.7 \pm 0.3$ & $720 \pm 61$ & $1.5 \times 10^{8} \pm 2.4 \times 10^{6}$ & No melt \\
\hline 20a-19 & 900 & 450 & 896.32 & 18.1 & $2.5 \times 10^{-5}$ & & & & \\
\hline $20 a-18$ & 950 & 450 & $\begin{array}{l}897.09 \\
703.92 \\
516.90\end{array}$ & $\begin{array}{r}9.3 \\
12.3 \\
15.6\end{array}$ & $\begin{array}{l}1.0 \times 10^{-4} \\
2.5 \times 10^{-5} \\
6.3 \times 10^{-6}\end{array}$ & $5.0 \pm 0.4$ & & & $\begin{array}{l}\text { Melt found } \\
\text { under TEM }\end{array}$ \\
\hline $20 a-34$ & 1000 & 500 & $\begin{array}{l}731.00 \\
549.00 \\
366.00\end{array}$ & $\begin{array}{l}10.6 \\
12.9 \\
15.1\end{array}$ & $\begin{array}{l}1.0 \times 10^{-4} \\
2.5 \times 10^{-5} \\
6.3 \times 10^{-6}\end{array}$ & $4.0 \pm 0.4$ & $699 \pm 55$ & $(5.8 \pm 2.8) \times 10^{12}$ & melt $<0.5 \%$ \\
\hline $20 a-37$ & 1050 & 500 & $\begin{array}{l}567.30 \\
410.50\end{array}$ & $\begin{array}{l}6.8 \\
8.6\end{array}$ & $\begin{array}{l}1.0 \times 10^{-4} \\
2.5 \times 10^{-5}\end{array}$ & 4.1 & & & melt $<1 \%$ \\
\hline 20a-17 & 1150 & 500 & $\begin{array}{r}141.60 \\
102.10 \\
71.50\end{array}$ & $\begin{array}{l}2.6 \\
4.6 \\
5.5\end{array}$ & $\begin{array}{l}1.0 \times 10^{-4} \\
2.5 \times 10^{-5} \\
6.3 \times 10^{-6}\end{array}$ & $4.1 \pm 0.1$ & & & melt $<5 \%$ \\
\hline
\end{tabular}

decrease with temperature increasing, but in the same sample, the stress decrease with strain rates typically decreasing from $1 \times 10^{-4}$ to $2.5 \times 10^{-5}$ and $6.3 \times 10^{-6} \mathrm{~s}^{-1}$.

\subsection{Steady-state flow law parameters}

We use the following equation to describe the steady-state flow:

$\stackrel{\bullet}{\varepsilon}=A \sigma^{n} \exp (-Q / R T)$,

where $\dot{\varepsilon}$ is the axial strain rate, $\sigma$ is the differential stress, $A$ is a material constant, and $Q$ is the activation energy, $R$ is the gas constant, and $T$ is absolute temperature.

From the relation between differential stress and strain rate, the stress exponent $n$ is calculated by Eq. (1). The results show that $n$ decreases systematically with the increasing temperature (Table 1) and levels off to $4-5$ above $950^{\circ} \mathrm{C}$, a value typical for dislocation creep. With temperature lower than $950{ }^{\circ} \mathrm{C}$, the deformation transits from power-law creep to power-law-breakdown creep, in which regime the stress exponent reaches a maximum value of 16.5 at the lowest temperature $700{ }^{\circ} \mathrm{C}$. We also employ Eq. (1) to describe the power-law-breakdown creep.

In terms of strength, stress exponent, and deformation mechanisms, the activation energy was calculated separately in three temperature regions. In the calculation, strain rates are first converted to values corresponding to a constant stress of $500 \mathrm{MPa}$, then activation energy is calculated for each temperature region. The results are as follows: (1) for temperature of $700{ }^{\circ} \mathrm{C}-800{ }^{\circ} \mathrm{C}, n=14.6$, $Q=612 \pm 12 \mathrm{~kJ} / \mathrm{mol}$; (2) for $900{ }^{\circ} \mathrm{C}-950{ }^{\circ} \mathrm{C}, n=6.4$, $Q=720 \pm 12 \mathrm{~kJ} / \mathrm{mol}$; (3) $1000{ }^{\circ} \mathrm{C}-1150{ }^{\circ} \mathrm{C}, \quad n=4.1$, $Q=699 \pm 55 \mathrm{~kJ} / \mathrm{mol}$.

\section{Deformation microstructures}

The microstructures of experimentally deformed samples were observed using TEM. 
4.1 Microstructures of semi-brittle deformation at $700{ }^{\circ} \mathrm{C}-850{ }^{\circ} \mathrm{C}$

At $700{ }^{\circ} \mathrm{C}-850{ }^{\circ} \mathrm{C}$, samples show homogeneous shortening in macroscopic scale. Undulatory extinction, deformation bands and mechanical twins are found in plagioclase under optical microscope. Microfractures occurred within both plagioclase and clinopyroxene. TEM observations show mechanical twins (Fig. 2a, b) and tangled dislocations with high density in most plagioclase grains (Fig. 2c). Dislocations in clinopyroxene are not fully developed, and distributed in moderate density (Fig. 2d). Hence in this temperature range, the microstructures imply that the deformation is accommodated by semi-brittle flow, which in the microscopic scale corresponds to dislocation glide and mechanical twinning accompanied with microfracturing.
4.2 Microstructures of low-temperature plastic deformation at $900{ }^{\circ} \mathrm{C}-950{ }^{\circ} \mathrm{C}$

At $900{ }^{\circ} \mathrm{C}-950{ }^{\circ} \mathrm{C}$, samples are uniformly shortened in macroscopic scale and show little evidence of microfracture both in macroscopic and microscopic scales. Undulatory extinction, mechanical twins and macroscopic preferred orientation of grains are major features for plagioclase under optical microscope. In addition, the edges and corners of some plagioclase are blurred by deformation. Another notable phenomenon is the appearance of opaque substance on the boundaries of some plagioclase grains. This implies redistribution of opaque impurities during deformation. At $900{ }^{\circ} \mathrm{C}$, TEM observations show dislocation density is high in most plagioclase grains (Fig. 3a), but very low in some grains (Fig. 3d). Mechanical twins can also be seen in some

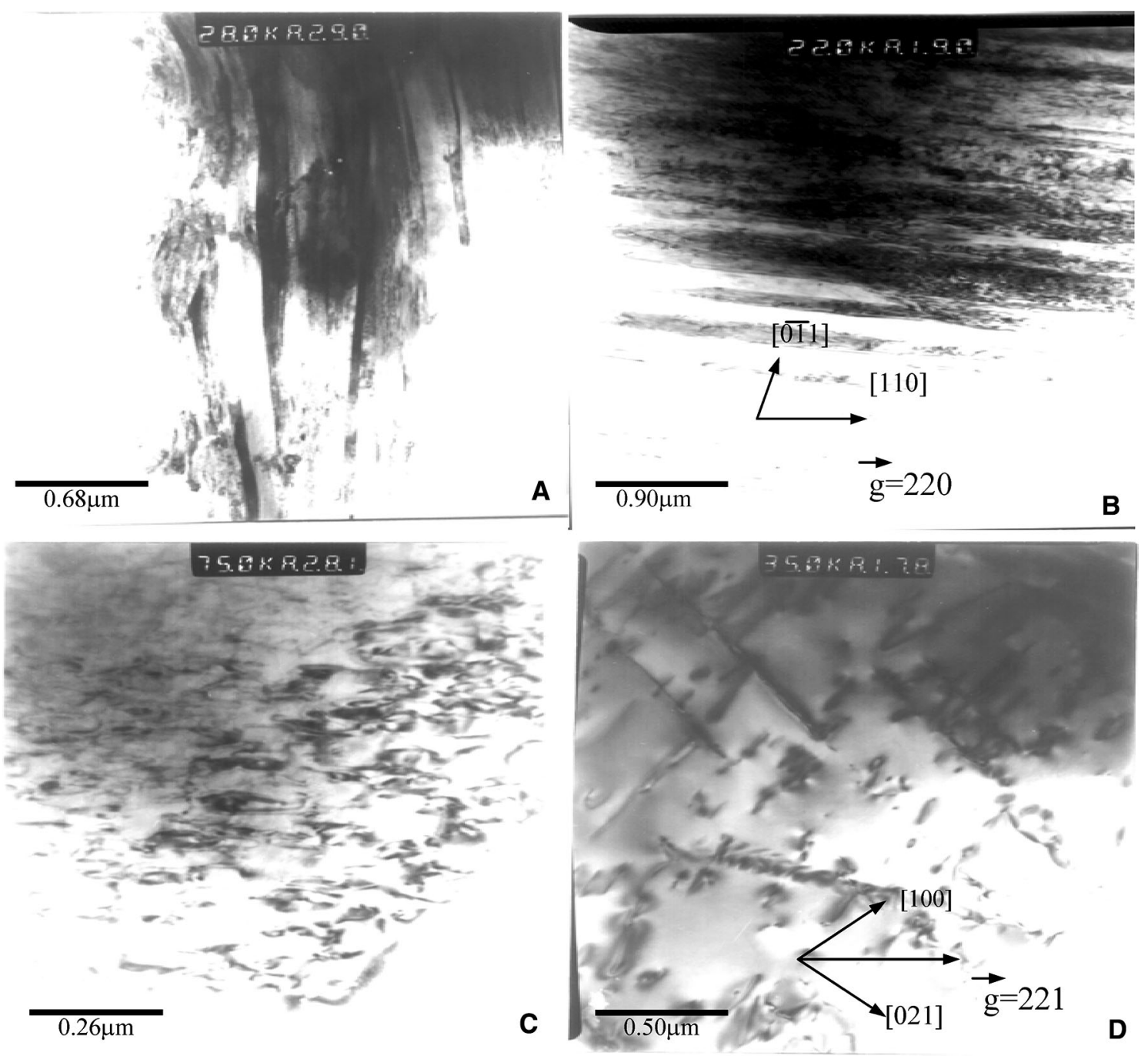

Fig. 2 TEM micrographs of dislocation at $700{ }^{\circ} \mathrm{C}-800{ }^{\circ} \mathrm{C}$. a, b Mechanical twins in plagioclase; c High density of tangled dislocations of plagioclase; d Straight dislocations of clinopyoxene 

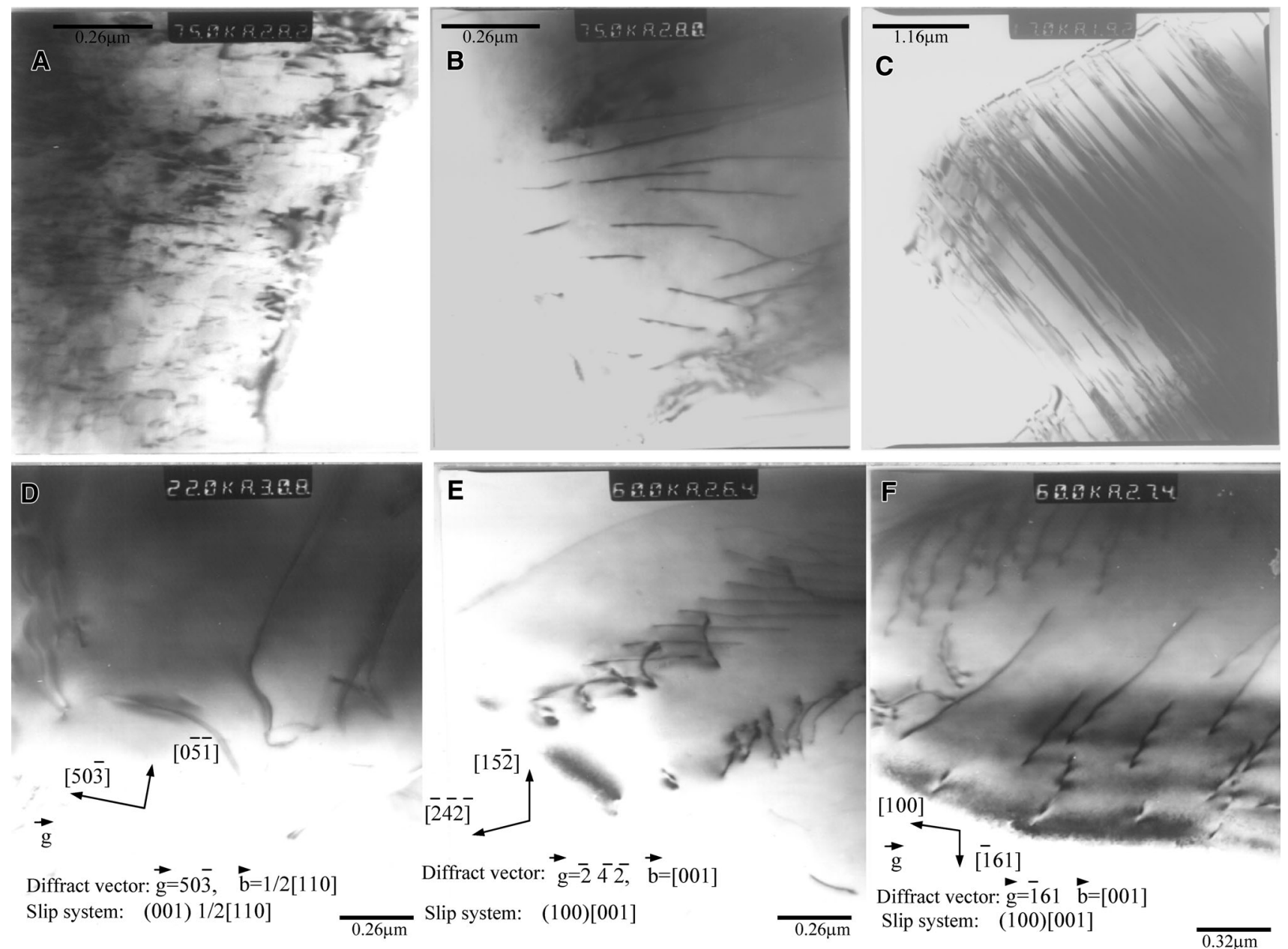

Fig. 3 TEM micrographs of dislocation at $900{ }^{\circ} \mathrm{C}$. a Dislocation density is high in plagioclase; b Dislocation density is moderate in clinopyoxene; $\mathbf{c}$ mechanical twins in plagioclase; $\mathbf{d}$ Dislocation density is low in plagioclase; e Dislocation density is moderate in clinopyoxene; f Dislocation density is moderate in clinopyoxene

plagioclase grains (Fig. 3c). The dislocation lines in most clinopyroxene grains are well developed and the density is moderate (Fig. 3b, e, f). Distribution of dislocations is uniform and the density is moderate in magnetite grains. At $950{ }^{\circ} \mathrm{C}$, dislocations in clinopyroxene are tangled (Fig. 4a-c) with moderate but higher density than that at $700{ }^{\circ} \mathrm{C}-800{ }^{\circ} \mathrm{C}$ and $900{ }^{\circ} \mathrm{C}$, while the dislocations in plagioclase are regularly distributed in moderate density (Fig. 4d-g). Increased density and tangled feature of dislocations in clinopyroxene suggest increased partitioning of stress on clinopyroxene grains. In addition, a very small amount of melt was found on grain boundaries of plagioclase under TEM at $950{ }^{\circ} \mathrm{C}$. These observations show that the predominant deformation mechanisms in this temperature range are dislocation glide accompanied with mechanical twinning. The observed slip system of plagioclase is (001)1/2[110] (Fig. 3d), and the observed slip systems of clinopyroxene are (100) [001] (Fig. 3e, f) and (010)[001] (Fig. 4a).

\subsection{Microstructures of high-temperature plastic deformation at $1000{ }^{\circ} \mathrm{C}-1150{ }^{\circ} \mathrm{C}$}

At temperature of $1000{ }^{\circ} \mathrm{C}-1150{ }^{\circ} \mathrm{C}$, samples are uniformly shortened and show no evidence of microfracture. Under optical microscope, the edges and corners of most plagioclase grains get blurred and rounded, and again, opaque substance appeared on the boundaries of plagioclase grains. Partial melting less than $5 \mathrm{vol} \%$ is widely distributed around grain boundaries. TEM observations show that dislocation is complicated and the density is heterogeneous in plagioclase (Fig. 5a-c). In addition to a few types of dislocation distribution (Fig. 5a-c), dislocation walls also appeared in plagioclase (Fig. 5d, e), implying that both dislocation climb and glide are active in this temperature range. In clinopyroxene grains, dislocations are regularly distributed (Fig. 5f) with moderate, but lower density than that at $900{ }^{\circ} \mathrm{C}-950{ }^{\circ} \mathrm{C}$. All these observations suggest that the major deformation 


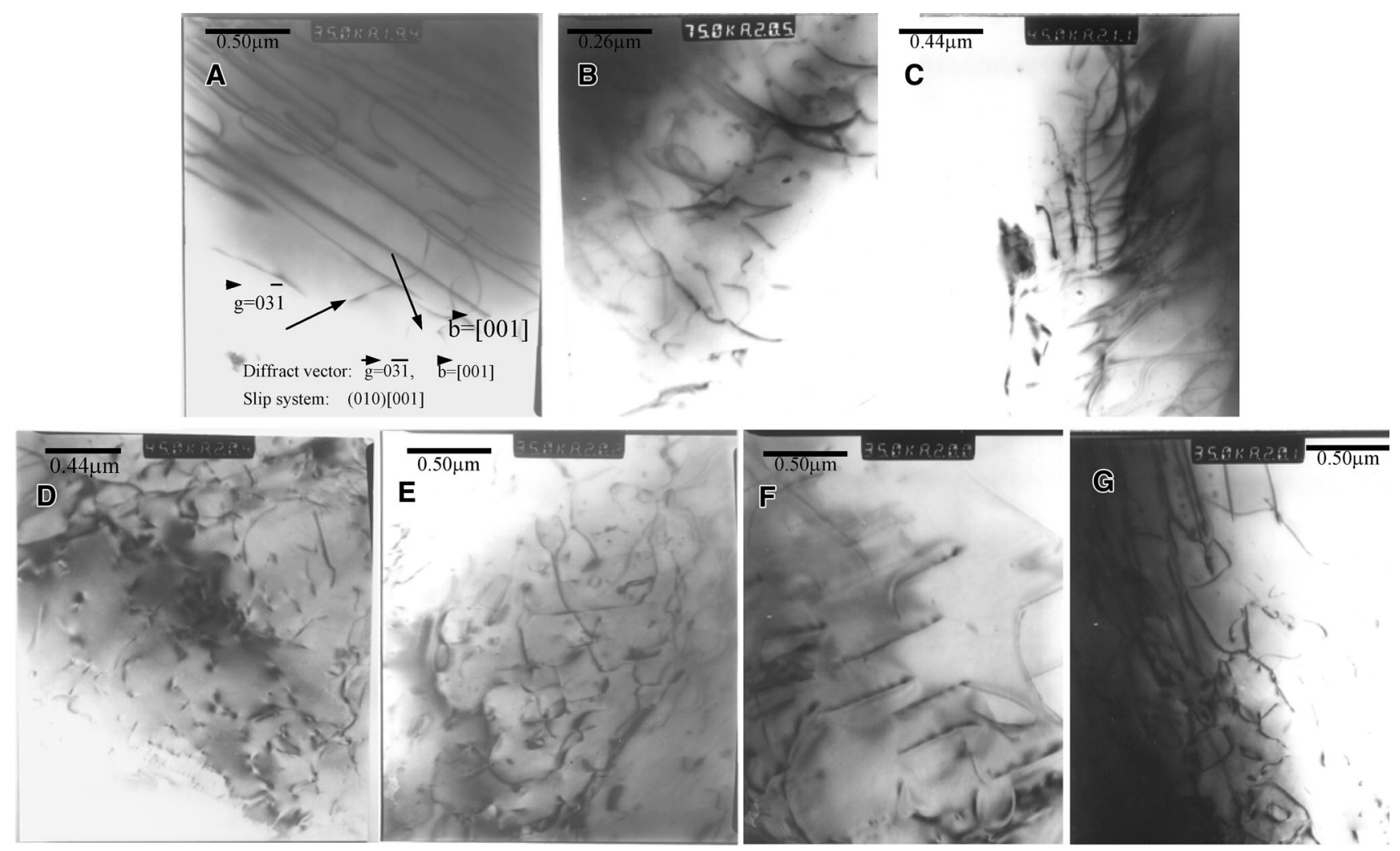

Fig. 4 TEM micrographs of dislocation at $950{ }^{\circ} \mathrm{C}$. a-c Dislocations in clinopyoxene are tangled, with moderate density; $\mathbf{d}-\mathbf{g}$ Dislocations in plagioclase are regularly distributed, with moderate density

mechanisms in this temperature range are dislocation glide and climb, with minor processes of partial melting.

Theory of dislocation (Weertman 1957, 1968) shows that the flow rate is usually controlled by dislocation climb when the stress exponent is $2-5$. The result of our experiments should be the case when temperature is higher than $950{ }^{\circ} \mathrm{C}$.

\subsection{Partial melt morphology at temperature of $950{ }^{\circ} \mathrm{C}-$ $1150{ }^{\circ} \mathrm{C}$}

Melt was first found at $950{ }^{\circ} \mathrm{C}$ under optical microscope and TEM. The melt morphology was observed under TEM. At $950{ }^{\circ} \mathrm{C}-1000{ }^{\circ} \mathrm{C}$, the melt glass distributed in two ways: melt thin film between two grain boundaries of plagioclase (Fig. 6a), and melt tubules of triangular cross section along three grain boundaries of plagioclase, where the dihedral angle of triple junctions approaches $60^{\circ}$ when the amount of melt is less than $0.5 \%$ (Fig. 6b). With the amount of melt increasing to $0.5 \%-1 \%$, the melt triangular crosssection with slightly curved boundaries become large and interconnected to local network along triple junctions, where the dihedral angle of triple junctions is less than $60^{\circ}$ (Fig. 6c). At $1050{ }^{\circ} \mathrm{C}$, the melt increased to an amount greater than $1 \%$, and was found not only between two grain boundaries of plagioclase, but also among two or three different mineral boundaries (Fig. 6d), such as in boundaries between plagioclase and clinopyroxene, and triple junctions of plagioclase, clinopyroxene, and magnetite. The boundaries of melt triangular cross section are curved and regular, and melt local networks are common (Fig. 6). The melt differentiated into two parts, one of which consists of iron-rich dark dots and another is silicaterich matrix in TEM pictures (Fig. 6d, e), some iron-rich melt (dark dots) crystallized into tree-shaped magnetite during cooling process (Fig. $6 \mathrm{e}-\mathrm{g}$ ). At $1150{ }^{\circ} \mathrm{C}$, the content of melt approaches $5 \%$, and melt is in regular thin films between some grains or in thick and irregular strips which wet most part of the grain boundary, and is interconnected to a network.

\section{Discussion: deformation mechanisms}

Optical and TEM observations show that deformation mode of the fine-grained gabbro is semi-brittle flow at low temperature and plastic flow at higher temperature. The deformation mechanisms of clinopyroxene observed by Kolle and Blacic (1982, 1983), Kirby and Kronenberg 

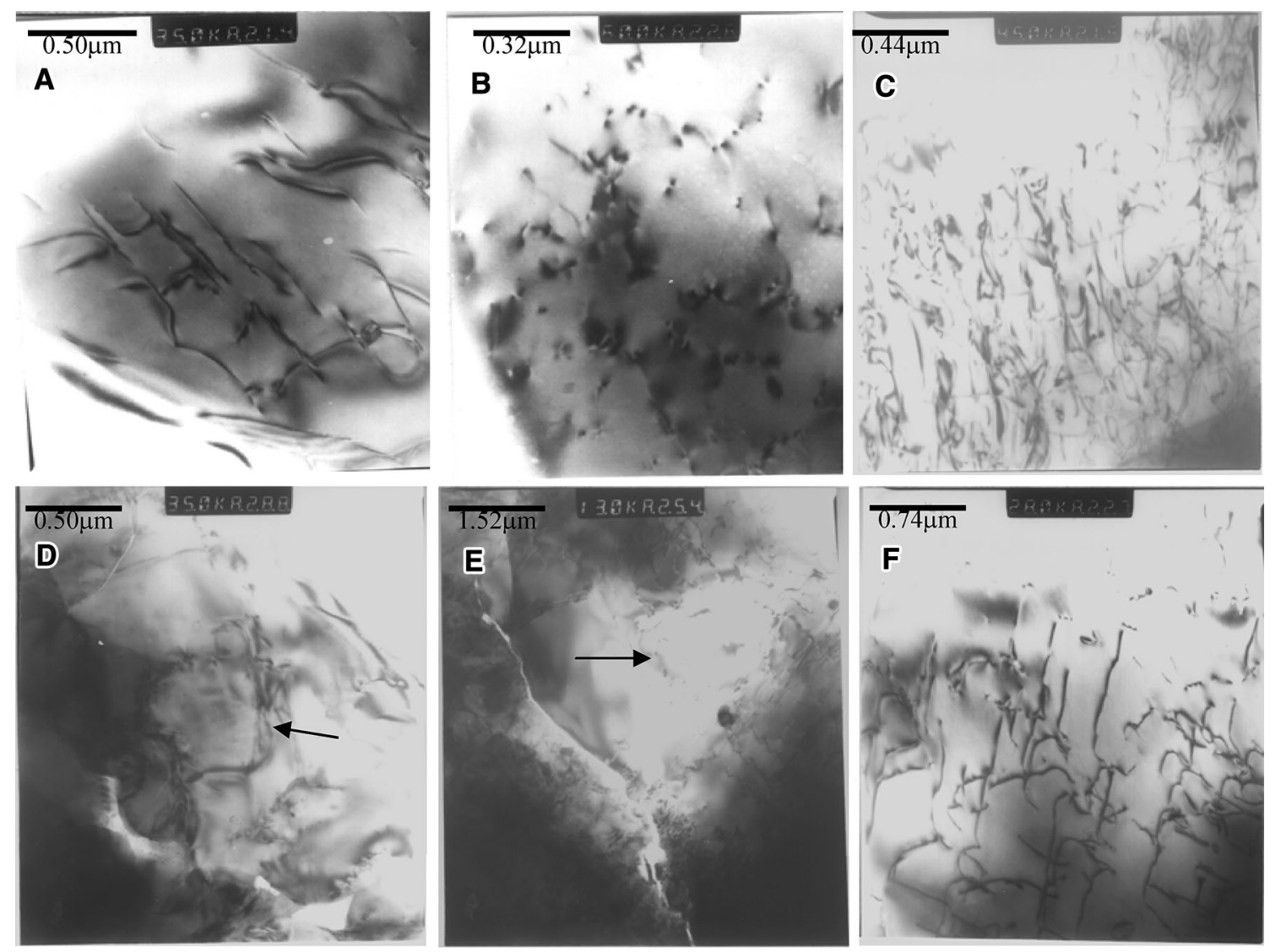

Fig. 5 TEM micrographs of dislocation at $1050{ }^{\circ} \mathrm{C}$. a-c Dislocations in plagioclase with moderate to high density; d, e dislocation walls (labeled by arrows) in plagioclase; f Regularly distributed dislocations in clinopyroxene with moderate density

(1984), Boland and Tullis (1986), and Mauler et al. (2000), and that of diabase observed by Kronenberg and Shelton (1980) and Caristan (1982) are mechanical twinning, dislocation glide and microfracture at low temperature, and dislocation glide and climb at high temperature, consistent with the deformation mode for fine-grained gabbro in our results.

The slip system (001)1/2[110] in plagioclase determined in our results is consistent with one of the two slip systems $((001) 1 / 2[110]$ and (010)[001]) in deformed plagioclase in natural gabbro (Ague and Wenk 1990). However, in the samples of plagioclase single crystals of An60 experimentally deformed at $900{ }^{\circ} \mathrm{C}$ and $1 \mathrm{GPa}$ confining pressure, dislocations of the [001](010) and $<110>(001)$ system are about equally abundant, whereas $<110>\{111\}$ is less common (Stunitz et al. 2003). The reason for difference with our results is the single crystals of plagioclase oriented with the (010)-plane normal to the compression direction, as well as oriented with the (010) plane at $45^{\circ}$ and the [001]-direction down dip in (010) (Stunitz et al. 2003).
In deformed clinopyroxene, we determined two slip systems: (100)[001] and (010)[001]. In previous studies on clinopyroxene aggregate, only one of the two systems ((100)[001]) was determined (Kronenberg and Shelton1980; Kolle and Blacic 1982, 1983; Kirby and Kronenberg 1984). On the other hand, in clinopyroxene single crystal deformed under high temperature and uniaxial compression (Raterron and Jaoul 1991), many slip systems have been determined, namely, (100)[001], \{110\}1/2 $<\mathrm{a} \pm \mathrm{b}>,\{110\}[001],(010)[100]$ and (100)[010]. Evidently, the slip system (010)[001] found in our experiments is new to the slip system family of clinopyroxene.

In previous experimental studies, twinning planes have also been determined. Kronenberg and Shelton (1980) showed that (010) and (001) are mechanical twinning planes for plagioclase in experimentally deformed Maryland diabase. Mechanical twinning planes (100)[001] and (001)[100] have been found in experimentally deformed clinopyroxene aggregates (Kronenberg and Shelton 1980; Kolle and Blacic 1982, 1983; Kirby and Kronenberg 1984; Boland and Tullis 1986). 




Fig. 6 Partial melting morphology of gabbro. a 20b-27(500 MPa $\left.950{ }^{\circ} \mathrm{C}\right)$; b 20a-34(500 MPa $\left.1000{ }^{\circ} \mathrm{C}\right)$; c 20b-27(500 MPa $\left.950{ }^{\circ} \mathrm{C}\right)$; d-h $20 \mathrm{a}-$ $37\left(500 \mathrm{MPa} 1050^{\circ} \mathrm{C}\right)$. Melt was labeled by arrows (pic. a-d); Melt consists of iron-rich particles and silicate matrix (pic. e); Iron-rich melt crystallized into magnetite (pic f, g); Opaque substance (iron-rich impurities) appeared on boundaries of plagioclase (pic. h., labeled by arrow)

\section{Conclusions}

We investigate microstructures and deformation mechanisms of experimentally deformed gabbro under TEM in this study. For low temperature of $700{ }^{\circ} \mathrm{C}$ to $950{ }^{\circ} \mathrm{C}$, the deformation is mainly accommodated with dislocation glide and mechanical twinning, corresponding to stress exponent lager than 5, which means semi-brittle deformation. Whereas with higher temperature up to $1000{ }^{\circ} \mathrm{C}-1150{ }^{\circ} \mathrm{C}$, the deformation is accommodated mainly with dislocation glide and climb corresponding to stress exponent of 4.1, which means plastic deformation. Evidence of dislocation climb has been found as dislocation walls in plagioclase. The observed slip system in plagioclase is (001)1/2[110] and the observed slip systems in clinopyroxene are (100)[001] and (010)[001]. The (010)[001] slip system in clinopyroxene is newly found in this work.

Melt was found at temperature of $950{ }^{\circ} \mathrm{C}-1050{ }^{\circ} \mathrm{C}$. The melt glass distributed both in melt thin film between two grain boundaries and melt tubules of triangular along three grain boundaries at temperature of $950{ }^{\circ} \mathrm{C}-1000{ }^{\circ} \mathrm{C}$. The melt triangular interconnected to the melt film at temperature of $1050{ }^{\circ} \mathrm{C}-1150{ }^{\circ} \mathrm{C}$, where the melt chemical composition differentiated into iron-rich dark dots and silicate-rich matrix.

Acknowledgments This research is sponsored by National Natural Science Foundation of China under grant No. 41374184) and State key laboratory of Earthquake Dynamics (Grant No. LED2013A05). We also thank three reviewers for their valuable comments.

Open Access This article is distributed under the terms of the Creative Commons Attribution License which permits any use, distribution, and reproduction in any medium, provided the original author(s) and the source are credited.

\section{References}

Ague DM, Wenk H (1990) Deformation microstructures and lattice orientations of plagioclase in gabbros from central Australia. In: Duba AG, Durham WB, Handin JW, Wang HF (eds) The BrittleDuctile transition in rocks, geophy. Monogr. Ser. AGU, Washington, DC, pp 173-186

Boland JN, Tullis TE (1986) Deformation behavior of wet and dry clinopyroxenite in the brittle to ductile transition region. In: Hobbs $\mathrm{BE}$, Heard HC (eds) Mineral and rock deformation laboratory studies. Geophys. Monogr. Ser. AGU, Washington, DC, pp 35-50 Bystricky M, Mackwell S (2001) Creep of clinopyroxene aggregates. J Geophys Res 106:13443-13454 
Caristan Y (1982) The transition from high temperature creep to fracture in Maryland diabase. J Geophys Res 87:6781-6790

Chen S, Hiraga T, Kohlstedt DL (2006) Water weakening of clinopyroxene in the dislocation creep regime. J Geophys Res 111:B08203

Dimanov A, Dresen G (2005) Rheolgy of synthetic anorthite-diopside aggregates: implications for ductile shear zones. J Geophys Res 110(B7):B07203. doi:10.1029/2004JB003431

Dimanov A, Dresen G, Wirth R (1998) High-temperature creep of partially molten plagioclase aggregates. J Geophs Res 103(B5): 9651-9664

Dimanov A, Dresen G, Xiao X, Wirth R (1999) Grain boundary diffusion creep of synthetic anorthite aggregates: the effect of water. J Geophs Res 104(B5):10483-10497

Dimanov A, Lavie MP, Dresen G, Ingrin J, Jaoul O (2003) Creep of polycrystalline anorthite and diopside. J Geophys Res 108(B1): 2061. doi:10.1029/202JB001815

Dimanov A, Rybacki E, Wirth R, Dresen G (2007) Creep and straindependent microstructures of synthetic anorthite-diopside aggregates. J Struct Geol 29(6):1049-1069

Dimanov A, Raphanel J, Dresen G (2011) Newtonian flow of heterogeneous synthetic gabbros at high strain: grain sliding, ductile failure, and contrasting local mechanisms and interactions. Eur J Min 23:303-322

He C, Zhou Y, Sang Z (2003) An experimental study on semi-brittle and plastic rheology of panzhihua gabbro. Sci China (D) 46(7): 730-742

Hier-Majumder S, Mei S, Kohlstedt DL (2005) Water weakening of clinopyroxenite in diffusion creep. J Geophys Res 110:B07406. doi: $10.1029 / 2004 J B 0033414$

Ingrin J, Doukhan N, Doukhan JC (1991) High-temperature deformation of diopside single crystal 2. Transmission electron microscopy investigation of the defect microstructures. J Geophys Res 96:14287-14297

Jaoul O, Raterron P (1994) High-temperature deformation of diopside single crystal 3. Influences of $\mathrm{PO}_{2}$ and $\mathrm{SiO}_{2}$ precipitation. J Geophys Res 99:9423-9439

Kirby SH, Kronenberg AK (1984) Deformation of clinopyroxenite: evidence for a transition in flow mechanisms and semi-brittle behavior. J Geophys Res 89:3177-3192

Kolle JJ, Blacic JD (1982) Deformation of single-crystal clinopyroxenes: 1. Mechanical twinning in Diopside and Hedenbergite. J Geophys Res 87:4019-4034

Kolle JJ, Blacic JD (1983) Deformation of single-crystal clinopyroxenes: 2. Dislocation-controlled flow processes in Hedenbergite. J Geophys Res 88(B3):2381-2393

Kronenberg AKK, Shelton GL (1980) Deformation microstructures in experimentally deformed Maryland diabase. J Struct Geol 2:341-353

Mackwell SJ, Zimmerman ME, Kohlstedt DL (1998) High-temperature deformation of dry diabase with application to tectonics on Venus. J Geophys Res 103:975-984
Mauler A, Bystricky M, Kunze K, Mackwell S (2000) Microstructures and Lattice preferred orientations in experimentally deformed clinopyroxene aggregates. J Struct Geol 22:1633-1648

Ohuchi T, Karato S, Fujino K (2011) Plastic deformation of orthopyroxene single crystals under the lithospheric conditions. Contrib Min Petrol 161:961-975

Raterron P, Jaoul O (1991) High-temperature deformation of diopside single crystal 1. Mechanical data. J Geophys Res 96:14277-14286

Raterron P, Doukhan N, Jaoul O, Doukhan JC (1994) High-temperature deformation of diopside single crystal IV: predominance of 110 glide above $100{ }^{\circ} \mathrm{C}$. Phys Earth Planet Inter 82:209-222

Ross JV, Wilks KR (1995) Effects of a third phase on the mechanical and microstructural evolution of a granulite. Tectonophysics 241:303-316

Ross JV, Wilks KR (1996) Microstructure development in an experimentally sheared orthopyroxene granulite. Tectonophysics 256:83-100

Rybacki E, Dresen G (2000) Dislocation and diffusion creep of synthetic anorthite aggregates. J Geophys Res 105:26017-26036

Rybacki E, Dresen G (2004) Deformation mechanism maps for feldspar rocks. Tectonophysics 382(173-187):2004. doi:10. 1016/j.tecto.01.006

Rybacki E, Gottschalk M, Wirth R, Dresen G (2006) Influence of water fugacity and activation volume on the flow properties of fine-grained anorthite aggregates. J Geophys Res 111:B03203

Rybacki E, Wirth R, Dresen G (2008) High-strain creep of feldspar rocks: implications for cavitation and ductile failure in the lower crust. Geophys Res Lett 35:L04304

Rybacki E, Wirth R, Dresen G (2010) Superplasticity and ductile fracture of synthetic feldspar deformed to large strain. J Geophys Res 115:B08209

Stunitz H, Fitz Gerald JD, Tullis J (2003) Dislocation generation, slip systems, and dynamic recrystallization in experimentally deformed plagioclase single crystals. Tectonophysics 372:215-233

Wang Y, Zhang J, Jin Z, Green HW (2012) Mafic granulite rheology: implications for a weak continental lower crust. Earth Planet Sci Lett 353-354(1):99-107

Weertman J (1957) Steady-state creep through dislocation climb. J Appl Phys 28:362-364

Weertman J (1968) Dislocation climb theory of steady-state creep. Trans Am Soc Met 61:681-694

Wilks KR, Carter NL (1990) Rheology of some continental lower crustal rocks. Tectonophysics 182:57-77

Zhou YS, Rybacki E, Wirth R, He CR, Dresen G (2012a) Creep of partially molten fine-grained gabbro under dry conditions. J Geophys Res 117:B05204. doi:10.1029/2011JB008646

Zhou YS, Rybacki E, Wirth R, He CR, Dresen G (2012b) Reaction accommodated creep of wet gabbro. Gordon research Conference on Rock Deformation, Feedback Processes in Rock Deformation. Proctor Academy, Andover, NH 